FACTA UNIVERSITATIS

Series: Economics and Organization Vol. 16, N ${ }^{\mathrm{o}} 1,2019$, pp. $103-116$

https://doi.org/10.22190/FUEO1901103A

Preliminary Communication

\title{
INSURANCE CLAIMS FRAUD IN HOMEOWNER'S INSURANCE: EMPIRICAL EVIDENCE FROM THE NIGERIAN INSURANCE INDUSTRY
}

UDC 368.1:343.72(669)

\section{Sunday Stephen Ajemunigbohun', Ogochukwu Augustine Isimoya², Pretoria Moun Ipigansi ${ }^{3}$}

\author{
${ }^{1}$ Lagos State University, Department of Insurance, Lagos State, Nigeria \\ ${ }^{2}$ University of Lagos, Department of Actuarial Science \& Insurance, Lagos State, Nigeria \\ ${ }^{3}$ Niger Delta University, Department of Finance, Banking and Insurance, Bayelsa State, Nigeria
}

\begin{abstract}
This study examines insurance claims fraud in homeowner's insurance with its empirical findings from the Nigerian insurance industry. In this study, a descriptive research design was employed while purposive sampling method was adopted for information selection. A structured questionnaire was used for data collection. 221 participants were drawn from 31 insurance companies, which were basically general insurance companies that represent $61 \%$ capacity of the industry in terms of market structure. Major statistical techniques employed in the study were simple frequency percentage and T-test statistics. While five relevant research questions were stated and to which verbal interpretation were provided, added with supporting evidence, two hypothetical statements were made. The study recommends that effective fraud deterrent should be in place so as to promote stable, confidence-based, result-oriented and trustworthy market environment, and government on its own part must not fail to exhibit the will-power to drive the anti-fraud strategy designed, built and modeled for the operational efficiency of insurance companies and effective service delivery in the heart of the insuring public. This research work contributes to existing knowledge in that it helps broaden the scope of the regulatory bodies on the need to continually engage academia, insurance practitioners, IT experts and other stakeholders in designing and building a more sustainable anti-fraud strategy in improving insurance market penetration and density.
\end{abstract}

Key words: Claims handling, Fraudulent process, Homeowner's insurance, Claims cost, Fraud detection and prevention

JEL Classification: G22, M21

Received July 21, 2018 / Revised October 14, 2018 / Revised November 11, 2018 / Revised February 28, 2019 / Accepted March 19, 2019

Corresponding author: Sunday Stephen Ajemunigbohun

Lagos State University, Department of Insurance, Lagos, Nigeria

E-mail: sunday.ajemunigbohun@lasu.edu.ng 


\section{INTRODUCTION}

Homeowner's insurance is one of the most recognized and permissible form of property insurance in the World (Commonwealth of Virginia, 2011; GAO, 2014; Grace et al., 2004). It has been noted to attract quite an appreciable premium value into the insurance portfolio of most property insurance providers which, in turn, gives a fillip to the financial confidence and capacity of the industry as a whole (Grace et al., 2001; Majewski, 2013). GAO (2014) stressed that whenever perils such as fire, flood, wildfires, lightning, theft, hurricane, etc. occur property, individual and communities get devastated by the destruction of their homes and possessions. Hence, these perils have a significant financial impact on homeowners, insurers and government (be it at the state or federal level).

The term 'claim' is a demand, according to Krishnan (2010), on an insurer towards fulfillment of a promissory facet of insurance contract with the policyholder. An earlier submission by Brooks et al. (2005) gave it as a demand upon recovery for a loss for which an insurance coverage had been sealed. Singh (2012) opined that for an insurer to achieve optimal operational efficiency in claims handling, they must look in the direction of enforcing conventional claims mechanisms, leveraging high level fraud detection techniques and innovating self-service process.

Fraud, according to Brennan (2012), is described as any deliberate act that contravenes laws, rules or policies with the intent to elicit unauthorized financial gains. Monetary Authority of Singapore (2012) sees it as activities involving intentions to profit dishonestly from or illicit benefit accruing to party with an intention to defraud or any other related persons. Past studies such as Ojikutu et al., 2011; Onaolapo, 2000; Yusuf \& Ajemunigbohun, 2015; Yusuf \& Babalola, 2009; had given their contributions with respect to insurance fraud and claims handling process. With clear observations, it shows that none of these studies had been able to touch on property insurance fraud with respect to homeowners.

However, in a study conducted by Tennyson (2002), it was established as an intertemporal problem that the insureds with more claims experience seem to have a lower tolerance for insurance fraud. Also commented in an earlier study by Tennyson (1997), that policyholders who think erroneously of their premium in an exorbitant manner are of the tendency to embrace fraud. While the study by Miyazaki (2009) pondered on the nexus between deductible and insurance fraud, the study of Dean (2004) directed his submission at ethical perception and fraudulent act ensued from individual policyholder.

In an attempt to investigate an issue of homeowner's insurance fraud and abuse, the following relevant research questions were formulated:

i. What are the perils with high fraud tendency in homeowner's insurance claim?

ii. What are the perils with high claims cost in homeowner's insurance?

iii. What are the major sources of insurance claims fraud in homeowner's insurance in Nigeria

iv. What is the frequency of insurance claims fraud annually detected in homeowner's insurance?

v. What are the factors inducing insurance claims fraud in homeowner's insurance?

The hypothetical propositions, therefore, were stated as below:

$\mathrm{Ho}_{1}$ : Adoption of claims fraud preventions have not significantly improved homeowners insurance delivery

$\mathrm{Ho}_{2}$ : Insurance claims fraud detections have not significantly reduced homeowners insurance claims cost 
This paper is aimed at realizing research outcomes that will enable identification of perils with high fraud tendency in homeowner's insurance claim; perils with high claims cost in homeowner's insurance; subsequently revealing major sources of insurance claims fraud in homeowner's insurance and determining frequency of insurance claims fraud annually detected in homeowner's insurance in Nigeria and identifying factors inducing insurance claims fraud in homeowner's insurance. In order to achieve set objectives, descriptive research is used and relevant statistical tests are implemented.

The paper has been structured in the following manner: introduction; research objectives and questions; review of relevant literature; methodology section which takes note of research design, sampling and data processing technique; results and discussion of findings; conclusion, recommendations, research implications and suggestions for further research.

\section{REVIEW OF RELEVANT LITERATURE}

Quite a number of studies were conducted in the past with respect to insurance claims fraud (Crocker \& Tennyson, 2002; Dionne et al., 2009; Gill \& Randall, 2015; Insurance Europe, 2013; Loughran, 2005; Roder \& Jamieson, 2005; Tennyson, 2008). The term 'fraud' according to Derrig and Krauss (1994), is seen as criminal acts, possibly beyond a reasonable doubt, that violate statutes, making the willful act of obtaining money or value for an insurer under false pretense or material Misrepresentation of a crime. As recorded by Kuria and Morange (2014), fraud is described as an omission or intention to making one gain advantage dishonestly in dealings that can be accomplished by knowingly concealing, suppressing, misrepresenting or non-disclosure of material fact relevant to transactions or financial decision; misappropriating assets; and abusing fiduciary responsibility or position of trust. An earlier submission by Gill et al. (1994) presupposed fraud in the insurance industry as intentionally making fictitious claims, inflating a claim or adding extra items to a claim, or being in any way dishonest with the intent of gaining more than legal entitlement.

However, insurance claims fraud will not only threaten the survival and profitability of an insurer, if not adequately addressed, but thus affects negatively its value system and probably detrimental to sustain its social and economic structure. To this direction, fraud is seen as representation of a threat to the core principles of solidarity that maintains the concept of insurance alive (Guillen, 2004; Viaene \& Dedene, 2004). According to Viaene et al. (2007), the cost component of an insurance claims fraud is borne directly by all insured parties in terms of increased premium rates. Picard (2013), in his view, stipulated that fraud by one policyholder impacts the welfare of the other policyholders and providers, and that the methodology under which the effect is spread is the contracts between the provider of insurance and policyholders. Singh et al. (2011) stressed that fraud in insurance transaction range in severity, from marginally exaggerated claims to one that deliberately cause accidents or damage through fraud risk exposure such as: employee-related fraud, vendorrelated third-party fraud, insurance applicants, and surrender of policy or claimants.

Accordingly, insurance claims fraud poses a serious risk for insurers and probably result in extra costs for their policyholders (Singh et al., 2011). SAS (2012) averred that fraud, in its real sense, usually weakens the financial position of the insurer and undermines its ability to provide competitive rates and also to underwrite respectable and potentially profit-driven 
business; and poses a greater premium cost to the policyholder. In a submission by Ramos et al. (2012), data for claims fraud costs in many industries is not always available, but the insurance sector provides prompt data that may serve as sentries of potential situations for integrity in business-to-business and consumer-to-business claims. Coalition Against Insurance Fraud (1999) suggested insurance fraud laws as being necessary to combat the increasing impact of fraud on the insurance cost.

However, three functional classifications of insurance fraud were proposed, according to Viaene and Dedene (2004), to include: internal vs. external, underwriting vs. claim, and soft vs. hard. According to Henderson et al. (2010), the most common external fraud plans, in the insurance industry, include: fraudulent claims, money laundering, secret commissions, and investment fraud; while internally, the most common fraud plans include: theft of cash/cheque, employee expense fraud, cash receipt/premium fraud/ receivable, fraudulent revenue/underwriting, commission fraud and non-compliance to regulation. Some other types of fraud affecting insurance providers are said to include: fake documentation, commission rebate, misspelling, and collusion between parties (Singh et al., 2011).

According to Ramos et al. (2012), an integrated framework with four pillars for effective claims fraud control in variety of industries has been suggested to include: an operating model which integrates activities to reduce claims fraud; focused managerial strategy in claims fraud with exact goals and priorities; improving information access, quality and regularity to support analytical data; and leveraging data analytics to direct personnel's attention on high risk customers and claims. In earlier submission by Henderson et al. (2010), pertinent anti-fraud controls are expected to include: regular fraud risk assessment, governance (.i.e. oversight by the audit committee and board of directors), ethical code of business, incident reporting systems, investigative protocol, remediation procedure, hiring and improvement policies and guidelines, and management control and testing.

Roder and Jamieson (2005) opined that the true economic cost of insurance is near impossible to measure. In the work by Chartered Global Management Accountant (2012), effective anti-fraud strategies were suggested to involve: prevention, detection, response and deterrence. In furtherance of its work, it was noted that the quantification of prevention, detection and response can help to create an effective fraud deterrent; in that, while fraud prevention strategy is noted to comprise sound ethical culture and internal control mechanisms, the core tools for detecting fraud include training and experience combined with the essential mindset that fraud is always a possibility. Lexis-Nexis (2014) suggested that tactics to preventing insurance fraud must be linked with insurers' operational activities to guarantee the following: ensuring secure information management, improving efficiency in operation, enhancing efficient investigation, reducing false-positive outcome, and facilitating compliance with world regulations.

\section{OVERVIEW OF THE NIGERIAN INSURANCE INDUSTRY}

The Nigerian Insurance Industry is governed by the National Insurance Commission. The guiding principle regulating the affairs of the industry is Insurance Act 2003 as amended in 2005. The insurance industry in Nigeria is still growing and developing. Moreover, it only contributes $0.7 \%$ toward Gross Domestic Product (GDP) as juxtapose to other markets such as South Africa with penetration status of about $12 \%$ (PricewaterhouseCoopers International, 2015). 
The Nigerian Insurance Industry experienced a landmark change in the year 2008 with a post consolidation exercise that produced 49 insurance companies and 2 reinsurance companies, a total market capitalization of over N600 billion (Babington-Ashaye, 2009). However, the Nigerian Insurance Industry is composed of four strategic players: insurers and reinsurers, insurance brokers, agents, and loss adjusters. The industry primarily focuses on broker driven corporate account especially the oil and gas sector. Brokers are dominant insurance distribution channels in the Nigerian Insurance Industry.

For strategic desire to be achieved in improving penetration level, the National Insurance Commission (NAICOM) came up with the Market Development and Restructuring Initiative in 2009, among others, purposely to enforce compulsory insurance and eradicate 'fake' policies. By this initiative, 6 insurance products were made obligatory with occupiers' liability insurance - section 65 of the insurance Act 2003 inclusive. With an estimated insurance penetration rate at 0.47 , and only $1 \%$ of the population holding any form of insurance policy, the opportunities in the Nigerian markets are substantial. In 2016, the industry's Gross Premium Income (GPI) grew by an estimated 10\% to N356 billion (Agusto \& Co. Research, 2017).

There is an increasingly experienced claims payment as is typical in the period of recession. The Nigerian insurance industry is no different. In 2016, net claims paid by operators amounted to an estimated N100 billion (\$ 327 million @ N305/\$), a 19\% growth over the preceding year. According to Ufomadu (2017), profitability is hampered by weak investment returns, raising maintenance and acquisition expenses as well as increasing claims.

\section{RESEARCH METHODS}

This study adopted descriptive research design. The motive for its use was due to its provision of germane interested facets to the researchers and also observation of the occurrence of sample items without any form of manipulation (Asika, 2008; Sekaran, 2003). It has also been noted to have the capacity to predict dispositions and, thus, assist in collecting the same information concerning all samples (Easterby-smith et al., 2008; Saunders et al., 2009). Data collection was conducted through the field survey among insurance companies with the assistance of structured questionnaire. The use of this data gathering source was because of its appropriateness to the design of the research (Babbie, 2005). The data gathering instrument further helped the researcher to elicit responses via its completion by adopting Likert-scaling measurement attached with a covering letter.

The target population comprises the entire members of staff within the sampling frame of 51 insurance companies operating presently in Nigeria (List of registered insurance companies in Nigeria, 2016), out of which a sampling unit of 31 insurance companies (specifically, general insurance companies) were surveyed giving a sample size of 221 respondents through the distribution of 10 questionnaires per surveyed company. The sampling frame was drawn within the Lagos metropolis hence it houses a larger percentages of insurance firms in Nigeria. For due diligence and genuine response, frequent phone calls and visits by research assistants were made to hasten proper filling and returning of the questionnaire. Ultimately, among 310 copies of questionnaires distributed, 221 were found useful for analytical results, giving a $71 \%$ response rate. 
Regarding the research validity, theoretical and content were choices of validity. While the former was carried out via variable measures from extant literature, the latter was designed via the administration of a set of questionnaire drafts to scanty selected insurance claims officers, research and development officers, and academia in the insurance profession. Eventually, experts deeply pondered on this instrument and gave commendable instructions within the respondents' comprehension. On the level of reliability, 0.814 was recorded as the Cronbach alpha with high sense of indication that the instrument surpassed the required standard of 0.70 .

\section{RESULTS AND DISCUSSION}

The simple frequency percentage table was used to analyse the above-stated research questions with the support of verbal interpretation.

In a bid to analyse the hypotheses formulated in this study, the T-test statistical technique was employed.

\subsection{Analysis of Research Questions}

Table 1 Perils with high fraud tendency in homeowner's insurance claim

\begin{tabular}{lcc}
\hline Alternatives & Responses & Percentages (\%) \\
\hline Fire & 98 & 44.3 \\
Burglary & 48 & 21.7 \\
Theft & 36 & 16.3 \\
Flood & 21 & 9.5 \\
Windstorm & 11 & 5.0 \\
Lightning & 07 & 3.2 \\
\hline Total & 221 & 100.0 \\
\hline \multicolumn{2}{c}{ Source: Field Survey, 2017 }
\end{tabular}

The table above shows that perils with high fraud tendency in homeowner's insurance are fire, followed by burglary, theft, flood, windstorm and lightning. To corroborate this evidence, Commonwealth of Virginia (2011) opined that purchasing homeowner's insurance will not prevent fires, theft or some other types of loss, but it can assist in the recovery from financial effects of a loss.

Table 2 Perils with high claims cost in homeowner's insurance

\begin{tabular}{lcc}
\hline Alternatives & Responses & Percentages (\%) \\
\hline Fire & 82 & 37.1 \\
Burglary & 49 & 22.2 \\
Theft & 38 & 17.2 \\
Flood & 29 & 13.1 \\
Windstorm & 14 & 6.3 \\
Lightning & 09 & 4.1 \\
\hline Total & 221 & 100.0 \\
\hline
\end{tabular}

Source: Field Survey, 2017 
The results expressed in Table 2 imply that perils with high claims cost in homeowner's insurance are fire with $37.1 \%$, followed by windstorm, flood, burglary, theft and lightning. In a bid to support this evidence, the work of Amorose (2011) and Harrington and Niehaus (2006) opined that insurers that can minimize their costs of claims by just a single percent have the tendency to achieve substantial saving. They reiterated further that the amount of claim payouts and expenses is the largest spending category for an insurer, responsible for not less than $80 \%$ of premium income. SAS (2012) arguably stated that creating an impression before policyholders through claim payment could be expensive for an insurer to bear.

Table 3 Major sources of insurance claims fraud in homeowner's insurance in Nigeria

\begin{tabular}{lcc}
\hline Alternatives & Responses & Percentages (\%) \\
\hline Policyholders & 86 & 38.9 \\
Insurance brokers & 63 & 28.5 \\
Employees & 31 & 14.0 \\
Loss adjusters & 28 & 12.7 \\
Insurance agents & 13 & 5.9 \\
\hline Total & 221 & 100.0 \\
\hline
\end{tabular}

Source: Field Survey, 2017

The results from the table above show that policyholders are the highest source of insurance claims fraud with $38.9 \%$, followed by insurance brokers, employees, loss adjusters and insurance agents. As cited in Yusuf (2010), four classes of insurance fraud fully expressed in the table, have been said to include: policyholder fraud, intermediary fraud, internal fraud and insurer fraud. The study by Terisa (2010) gave supporting evidence that fraud might occur at different phases in the insurance transaction and by different parties ranging from insurance applicants (.i.e. new customers); policyholders (existing customers); third-party claimants; and professional (i.e. insurance brokers, employees of insurance firms, insurance agents, loss adjusters, whose services were required by insurers, etc) who provided services to claimants. Derrig (2002) aligned his view to say that the existence of insurance claim fraud is hinged upon information that is asymmetrically distributed between the policyholder and the corresponding insurance company. Dulleck and Kerschbamer (2006), International Association of Insurance Supervisors (2011), and Muller (2013) were of the opinions that, apart from policyholders, other actors potentially linked with the occurrence of insurance fraud include: insurance brokers, intermediaries and service providers.

Table 4 Frequency in insurance claims fraud annually detected in homeowner's insurance in Nigeria

\begin{tabular}{lcc}
\hline Alternatives & Responses & Percentages (\%) \\
\hline Less than 11 times & 19 & 8.6 \\
$11-20$ times & 57 & 25.8 \\
$21-30$ times & 79 & 35.7 \\
$31-40$ times & 39 & 17.7 \\
Above 40 times & 27 & 12.2 \\
\hline Total & 221 & 100.0 \\
\hline
\end{tabular}

Source: Field Survey, 2017 
The table shows that annual insurance claims fraud usually recorded in most insurance companies in Nigeria with respect to homeowner's insurance is between 21 to 30 times with $35.7 \%$, followed by $11-20$ times, $31-40$ times above 40 times and less than 11 times. This result, then, corroborates the study of Goel (2013) who arguably stated that claims managers must focus mainly on the most significant claims tasks that require their attention and also better use of their time. To substantially corroborate the evidence above, Johnson and Jones (2012) stipulated that the most occurring fraud risk exposures in insurance business are categorized into: false claims, exaggerated claims, multiple claims and inflation claims.

Table 5 Factors inducing insurance claims fraud in homeowner's insurance

\begin{tabular}{lcc}
\hline Alternatives & Responses & Percentages (\%) \\
\hline Personality of the insured & 87 & 39.4 \\
Economic/financial & 49 & 22.2 \\
Weak organisational system & 37 & 16.7 \\
Poor motivation of employees & 29 & 13.1 \\
Weak legal system to punish offenders & 19 & 8.6 \\
\hline Total & 221 & 100.0 \\
\hline \multicolumn{2}{c}{ Source: Field Survey, 2017 }
\end{tabular}

The result above clearly implies the personality of the insured as the most critical factors inducing insurance claims fraud in homeowner's insurance. To corroborate this findings, Gabaldon et al. (2014) opined that insured's decision with the intent of getting a greater indemnity that what is precisely owed under the contract is taken to be fraudulent, and the insurers attempt to control such imply a cost, which may either be passed onto other consumers of insurance in the form of inflated premium, or borne by the insurer in the form of reduced profit.

\subsection{Hypotheses Testing}

In an attempt to further investigate insurance claims fraud in homeowner's insurance in Nigeria's insurance industry, T-test statistical technique was employed for empiricaloriented results.

Table 6 Respondents' opinions on hypothetical proposition one

\begin{tabular}{lcc}
\hline Alternatives & Responses & Percentages (\%) \\
\hline Strongly Agree & 10 & 04.5 \\
Agree & 34 & 15.4 \\
Undecided & 22 & 10.0 \\
Disagree & 86 & 38.9 \\
Strongly Disagree & 69 & 31.2 \\
\hline Total & 221 & 100.0 \\
\hline
\end{tabular}

Source: Field Survey, 2017 
Table 7 Descriptive statistics for testing the adoption of claims fraud prevention and improvement of homeowner's insurance

\begin{tabular}{lcccc}
\hline & $\mathrm{N}$ & Mean & Std. Deviation & Std. Error Mean \\
\hline $\begin{array}{l}\text { Adoption of claims } \\
\text { fraud prevention and }\end{array}$ & 221 & 3.7692 & 1.17788 & .07923 \\
$\begin{array}{l}\text { improvement of } \\
\text { homeowner's insurance }\end{array}$ & & & & \\
\hline & Source: Authors' computation, 2017
\end{tabular}

Table 8 One-Sample T-test of the adoption of claims fraud prevention and improvement of homeowner's insurance

\begin{tabular}{|c|c|c|c|c|c|c|}
\hline & \multicolumn{6}{|c|}{ Test Value $=3$} \\
\hline & \multirow[t]{2}{*}{$\mathrm{T}$} & \multirow[t]{2}{*}{ df } & \multirow{2}{*}{$\begin{array}{c}\text { Sig. } \\
\text { (2-tailed) }\end{array}$} & \multirow{2}{*}{$\begin{array}{c}\text { Mean } \\
\text { Difference }\end{array}$} & \multicolumn{2}{|c|}{$\begin{array}{l}95 \% \text { Confidence interval } \\
\text { of the Difference }\end{array}$} \\
\hline & & & & & Lower & Upper \\
\hline $\begin{array}{l}\text { Adoption of claims } \\
\text { fraud prevention and } \\
\text { improvement of } \\
\text { homeowner's insurance }\end{array}$ & 9.705 & 220 & .000 & 0.76923 & 0.6137 & 0.9573 \\
\hline
\end{tabular}

Source: Authors' computation, 2017

The result in table 8 shows that the calculated p-value $(0.0000)$, which is lower than 0.05 , confirms that there is a statistically significant difference between average respondents' opinion on hypothetical proposition 1 and hypothetical value 3 . Hypothesis (Ho) which states that adoption of claims fraud preventions could not have significant improvement on homeowner's insurance delivery is rejected. It is, therefore, germane to note that survey participants have an opinion that adoption of claims fraud preventions could have significant improvement on homeowner's insurance. This result corroborates the study of Asikhia (2010) who had mentioned that until companies are able to deliver their service in an efficient manner, with service-oriented information systems, financial institutions may not be able to retain their customers. In support of the evidence to this result, Lexis-Nexis (2014) opined that tactics used to prevent insurance fraud must be integrated with insurers' operational activities to guarantee security of information management, operational efficiency improvement, investigation efficiency improvement, minimisation of false-positive results and promotion of compliance with global regulations. To deliver excellence in insurance claims handling, key components that ought to be in place are said to include: communication, culture and philosophy, people, claims procedure, infrastructure, data management, operations, monitoring and review (Association of Insurance and Risk Managers in Industry and Commerce, 2009; Yusuf et al., 2017). 
Table 9 Respondents' opinions on hypothetical proposition two

\begin{tabular}{lcc}
\hline Alternatives & Responses & Percentage (\%) \\
\hline Strongly Agree & 16 & 07.2 \\
Agree & 42 & 19.0 \\
Undecided & 28 & 12.7 \\
Disagree & 76 & 34.4 \\
Strongly Disagree & 59 & 26.7 \\
\hline Total & 221 & 100.0 \\
\hline \multicolumn{2}{c}{ Source: Field Survey: 2017 }
\end{tabular}

Table 10 Descriptive statistics for testing of claims fraud detection and homeowner's insurance claim costs

\begin{tabular}{lcccc}
\hline & $\mathrm{N}$ & Mean & Std. Deviation & $\begin{array}{c}\text { Std. Error } \\
\text { Mean }\end{array}$ \\
\hline $\begin{array}{l}\text { Claims fraud detection } \\
\text { and homeowner's } \\
\text { insurance claim cost }\end{array}$ & 221 & 3.5430 & 1.26642 & .08519 \\
\hline & Source: Authors' computation, 2017 &
\end{tabular}

Table 11 One-Sample T-test of claims fraud detection and homeowner's insurance claim costs

\begin{tabular}{lcccccc}
\hline & \multicolumn{5}{c}{ Test Value =3 } \\
\cline { 2 - 6 } & $\mathrm{t}$ & Df Sig.(2-tailed) & $\begin{array}{c}\text { Mean } \\
\text { Difference }\end{array}$ & $\begin{array}{c}\text { 95\% Confidence interval } \\
\text { of the Difference }\end{array}$ \\
\cline { 3 - 6 } & & & & & Lower & Upper \\
\hline $\begin{array}{l}\text { Claims fraud detection } \\
\begin{array}{l}\text { insurance claims cost } \\
\text { reduction }\end{array}\end{array}$ & 6.374 & 220 & .000 & 0.543 & 0.3761 & 0.7009 \\
\hline
\end{tabular}

Source: Authors' computation, 2017

The result in Table 11 shows that the calculated p-value $(0.0000)$, which is lower than 0.05 , confirms the statistical significance of difference between obtained and hypothetical level of agreement with the statement of hypothesis two. Hypothesis (Ho) which states that insurance claims fraud detections could not have significant effect on homeowner's insurance claims cost is rejected. It is, therefore, crucial to note that survey participants have an opinion that insurance claims fraud detections could have significant effect on homeowner's insurance claims cost. This result corroborates existing submission of the Chartered Global Management Accountant (2012), who had suggested training and experience combined with the necessary mindset that fraud is always a possibility as the key tools for detecting fraud. In furtherance of the supporting evidence by IBM (2012), taking an assessment technique, insurance companies are guaranteed with discovery of fraud by examining patterns on data; investigating fraud more efficiently by reducing false claims; accelerating investigations; and visualizing trends to continuously enhancing antifraud efforts. 


\section{CONCLUSION AND RECOMMENDATIONS}

Insurance claims fraud has been emphasized in a number of studies; therefore, not taking appropriate step to combat this menace could be devastating, not only to the Nigerian insurance market environment but also to the economy globally. However, insurance, among its contributions to the economy, has been said to promote financial stability; reduce fear; facilitate trade and commerce; and mobilize savings. This research work attempted to examine experts' opinion on insurance claims fraud in homeowner's insurance among selected insurance companies in Nigeria. Results from the study have evidence that, according to the subjective assessment of the surveyed employees of the selected insurance companies, the adoption of insurance claims fraud preventions might have significantly improved homeowner's insurance in Nigeria. Also, empirical results from the T-test analysis based on experts' opinion provide evidence that insurance claims fraud detections might have significantly reduced homeowner's insurance cost. In addition, the results equally showed that speedy, accurate, efficient and effective claims managerial process is thus germane for cost control, due to managerial risk process and capacity building in underwriting.

On recommendations, insurance companies are advised to strictly tackle major sources of insurance claims fraud not only in the homeowner's insurance, but also in other types of insurance, so as to minimise the cost effects on their claims responsibilities to the policyholders. Moreover, rigorous efforts should be made to ensure proper implementation of an anti-fraud strategy that would continuously curtail fraudulent activities within and outside the insurance market space. An effective fraud deterrent should be put in place and to which aggressive campaign should be mounted to promote a stable, confidence-based, result-oriented, and trustworthy market environment in the minds of the insuring populace. As to the regulatory authorities, efforts should be made to monitor the anti-fraud progress within and outside the Nigerian insurance market space, by creating a more reliable and sustainable data management system that has the capacity to capture any fraudulent attempt or committed fraudulent activities in the running of insurance companies in Nigeria. Government on its own part must not fail to exhibit the will-power to drive antifraud strategy mechanism that will enhance the operational efficiency of insurance companies and effective service delivery in the heart of the insuring public.

This research work contributes to knowledge in that it awakes the regulatory body on the need to continually engage academia, insurance practitioners, IT experts and other stakeholders in designing and building a more sustainable anti-fraud strategy in improving insurance market penetration and density. It further stresses the need for managers to be alive to their responsibilities in ensuring that loopholes in the claims managerial procedures are tackled. It benefits the insuring public in terms of effective policy delivery, rise in confidence level etc.

On suggestions for further studies, researchers can pull their weight into studying some of the factors inducing insurance claims fraud in other property-related insurance policies. Efforts could also be made by other researchers to find out if the various sources of insurance claims fraud in homeowner's insurance are applicable to other propertyrelated insurance policies. Lastly, other interested researchers can direct their research efforts towards insurance claims fraud response from insurance policyholders in Nigeria. 


\section{REFERENCES}

Agusto \& Co. Research. (2017). Agusto\& Co. unveils 2017 insurance industry report. Retrieve from: http://www.thisdaylive.com/index:php/2017/02/09/agusto-co-unveils-2017-insurance-industry-report/

Amorose, R.C. (2011). Driving operational excellence in claims management. USA: Deloitte Development

Asika, N. (2008). Research methodology in the behavioural sciences. Lagos: Longman Nigeria Plc

Asikhia, O. (2010). Customer orientation and firm performance among Nigerian small and medium scale business. International Journal of Marketing Studies, 2 (1), 197 - 212.

Association of Insurance and Risk Managers in Industry and Commerce (2009). Delivery excellence in insurance claims handling: Guide to best practice. London: AIRMIC.

Babbie, E. (2005). The basic of social research. $3^{\text {rd }}$ edition, Canada: Thomson Learning Inc.

Babington-Ashaye, F. (2009). Re-engineering the insurance industry. Risk Analysts Insurance Broker Limited, Lagos, Nigeria.

Brennan, P. (2012). A comprehensive survey method for overcoming the class imbalance problem in fraud detection. M.Sc Dissertation. Institute of Technology, Dublin, Ireland.

Brooks, P.J., Popow, D.J. \& Hoopes, D.L. (2005). Introduction to claims. Pennsylvania: American Institute for Chartered Property Casualty Underwriters.

Chartered Global Management Accountant (2012). Fraud risk management: CGMA report. New York: Association of International Certified professional Accountants.

Coalition Against Insurance Fraud (1999). Model insurance fraud act: Summary of provision.

Commonwealth of Virginia (2011). Homeowner's insurance consumer's guide. Virginia: Commonwealth of Virginia State Corporation Commission.

Crocker, K. \&Tennyson, S. (2002). Insurance fraud and optimal claims settlement strategies. Journal of Law and Economics, 45 (2), 469 - 507.

Dean, D.H. (2004). Perceptions of the ethicality of consumer insurance claim fraud. Journal of Business Ethics, 54 (1), 67 - 79 .

Derrig, R.A. (2002). Insurance fraud. Journal of Risk and Insurance, 69 (3), 271 - 287.

Derrig, R.A. \& Krauss, L. (1994). First steps to fight workers' compensation fraud. Journal of Insurance Regulation, 12 (3), 390-415

Dionne, G.; Giuliano, F. \& Picard, P. (2009). Optimal auditing with scoring: Theory and application to insurance fraud. Management Science, 55 (1), 58 - 70.

Dulleck, U. \& Kerschbamer, R. (2006). On doctors, mechanics and computer specialists: The economics of credence goods. Journals of Economic Literature, 44 (1), 5 - 42.

Easterby-Smith, M., Thorpe, R. \& Jackson, P.R. (2008). Management research. $3^{\text {rd }}$ edition, London: Sage.

Gabaldon, I.M., Hernandez, F.J.V. \& Watt, R. (2014). The effect of contract type on insurance fraud. Journal of Insurance Regulation, 33 (8), 1 - 34.

Gill, K.M., Woolley, K. \& Gill, M. (1994). Insurance fraud: The business as a victim. In M.Gill (Ed.). Crime at work (pp. 73 -83). Leicester: Perpetuity Press.

Gill, M. \& Randall, A. (2015). Insurance fraudsters: A study for the ABI. UK: Perpetuity Research and Consultancy International Limited.

GAO (2014). Homeowners insurance: Multiple challenges make expanding private coverage difficult. Washington DC: United State Government Accountability Office.

Goel, C. (2013). Insurance claims management: improving staff capacity using BPM. London: Cognizant Business Consulting.

Grace, M.F., Klein, R.W. \& Kleindorfer, P.R. (2001). The demand for homeowners insurance with bundled catastrophic coverages (Center for Risk Management and Insurance Research Working Paper, 01 -05). Georgia State University

Grace, M.F., Klein, R.W. \& Kleindorfer, P.R. (2004). Homeowners insurance with bundled catastrophic coverages. The Journal of Risk and Insurance, 71 (3), 351 - 379.

Guillen, M. (2004). Fraud in insurance. In: Teugels, T., \& Sundit, B. (Eds.). Encyclopedia of Actuarial Science (2, 729 -739). London: Wiley.

Harrington, S.E. \& Niehaus, G.R. (2006). Risk management and insurance. Ney York: McGraw-Hill.

Henderson, S.P., Haywood, R. \& Mooney, K. (2010). Investigating fraud in the insurance industry: Are you prepared? 2009 Global Economic Crime Survey. Pricewaterhouse Coopers, 21 June

IBM (2012). Insurance claims fraud assessment: Reducing loss costs by combining insurance claims fraud. USA: IBM Corporation.

Insurance Europe (2013). The impact of insurance fraud. Brussels: Insurance Europe aisbl. 
International Association of Insurance Supervisors (2011). Application paper on deterring, preventing, detecting, reporting and remedying fraud in insurance. Technical Report.

Johnson, M. \& Jones, N. (2012). Insurance fraud in the digital age. UK: Gower publishing.

Krishnan, B. (2010). Claims management and claims settlements in life insurance. The Journal of Insurance Institute of India, 36 (July-December), 49-57.

Kuria, J.T. \& Moronge, M. (2014). Effect of fraud control mechanisms of the growth of insurance companies in Kenya. International Journal of Innovative Social \& Science Education Research, 2(1), 26-39.

Lexis-Nexis (2014). Key factors for prayers in fraud and abuse prevention: Protect against fraud and abuse with a multi-layered approach to claims management. Lexis-Nexis. Retrieved from: http://www.lexixnexis.com/ risk/healthcare.

List of registered insurance companies in Nigeria (2016). Punch Newspaper, 12 October

Loughran, D. (2005). Deterring fraud: The role of general damage awards in automobile insurance settlements. Journal of Risk and Insurance, 72 (4), 551 - 575.

Majewski, P. (2013). Insurance crime in Poland: Characterisation and evolution of the phenomenon. Insurance Review, 4, $121-132$.

Miyazaki, A.D. (2009). Perceived ethicality of insurance claims fraud: Do higher deductibles lead to lower ethical standard? Journal of Business Ethics, 87 (4), 589 - 598.

Monetary Authority of Singapore (2012). Guidelines on risk management practices for insurance business: Insurance fraud risk, 19, 1 - 11 .

Muller, K. (2013). The identification of insurance fraud: An empirical analysis (Risk Management and Insurance, Working Papers, 137), Switzerland: Institute of Insurance Economics, University of St. Gallen.

Ojikutu, R.K., Yusuf, T.O. \& Obalola, M.A. (2011). Attitude and perception about insurance fraud in Lagos State, Nigeria. European Journal of Scientific Research, 57 (4), 615-625.

Onaolapo, A. (2000). Detecting and handling fraud in insurance claims. Being a paper delivered at the Workshop on advanced claims management by FAS Consultants, July 28

Picard, P. (2013). Economic analysis of insurance fraud. In: G, Dionne (Edn.). Handbook of insurance. $2^{\text {nd }}$ edition. New York: Springer.

PriceWaterhouseCooper International (2015). Strategic and emerging trends in insurance markets in Nigeria. Insurance Industry Survey 2015, $1-81$.

Ramos, C., Kinzie, J. \& Epps, D. (2012). Reducing claims fraud: A cross-industry issue. UK: Deloitte Touche Tohmatsu Limited.

Roder, S. \& Jamieson, G. (2005). Insurance fraud: The victimless crime. Hong Kong: KMPG International.

SAS (2012). Combating insurance claims fraud: How to recognise and reduce opportunistic and organized claims fraud. USA: SAS Institute Inc.

Saunders, M., Lewis, P. \& Thornhill, A. (2009). Research methods for business students. $5^{\text {th }}$ edition, Essex: Pearson Education Limited.

Sekaran, U. (2003). Research methods for business: A skill-building approach. $4^{\text {th }}$ edition, USA: John Wiley \& Sons, Inc.

Singh, A., Parekh, A., Indge, R., Bali, S. \& Torpey, D. (2011). Fraud in insurance on rise: Survey 2010-2011. India: Ernst \& Young Pvt. Limited.

Singh, V. (2012). Global trends in non-life insurance: Claims Capgemini. https://www.capgemini.com/ ..../global_trends_in.online_insurance_2012_claims.pdf

Tennyson, S. (1997). Economic Institutions and individual ethics: A study of consumer attitudes toward insurance fraud. Journal of Economic Behaviour and Organisation, 32 (2), 247 - 265.

Tennyson, S. (2002). Insurance experience and consumer attitudes towards insurance fraud. Journal of Insurance Regulation 21(2), 35 - 55.

Tennyson, S. (2008). Moral, social and economic dimensions of insurance claims fraud. Social Research, 74 (4), $1181-1204$.

Terisa, R. (2010). Improving the defense lines: The future of fraud detection in the insurance industry with fraud risk models, text mining and social networks. Marlow: SAS Institute Limited

Ufomadu, A. (2017). Nigerian insurance industry: Overview, challenges and opportunities. Africa's Insurance Markets, May 27.

Viaene, S. \& Dedene, G. (2004). Insurance fraud: Issues and challenges. The Geneva Papers on Risk and Insurance, 29 (2), 313 -333.

Viaene, S., Ayuso, M., Guillen, M., Gheel, D.V. \& Dedene, G. (2007). Strategies for detecting fraudulent claims in the automobile insurance industry. European Journal of Operational Research, 176 (1), 565 - 583.

Yusuf, T.O. \& Ajemunigbohun, S.S. (2015). Effectiveness, efficiency and promptness of claims handling process in the Nigerian Insurance industry. European Journal of Business and Economics, 10 (2), 6-10. 
Yusuf, T.O., Ajemunigbohun, S.S. \& Alli, N.G. (2017). A critical review of insurance claims management: A study of selected insurance companies in Nigeria. SPOUDAI Journal of Economics and Business, 67 (2), $69-84$.

Yusuf, T.O. (2010). Brokers and the control of post contractual opportunism in the Nigerian Insurance market. Journal of Financial Crime, 17 (2), 223-239.

Yusuf, T.O. \& Babalola, A.R. (2009). Control of insurance fraud in Nigeria: An exploratory study (case study). Journal of Financial Crime, 16 (4), 418-435.

\section{PREVARE U OBLASTI OSIGURANJA IMOVINE: EMPIRIJSKI DOKAZI IZ NIGERIJSKE INDUSTRIJE OSIGURANJA}

Ova studija ispituje prevare osiguranja $u$ vezi sa zahtevima za naknadu štete u oblasti osiguranja imovine sa empirijskim nalazima iz industrije osiguranja u Nigeriji. Korišćena je deskriptivna metoda istraživanja dok je ciljna metoda uzorkovanja usvojena za izbor informacija. Za prikupljanje podataka korišćen je strukturirani upitnik. Učestvovao je 221 ispitanik iz 31 osiguravajućeg društva, koja su u osnovi kompanije za opšte osiguranje i koja predstavljaju $61 \%$ kapaciteta industrije u pogledu strukture tržišta. Glavne statističke tehnike korišćene u studiji bile su jednostavni procenat frekvencije i T-test statistika. Postavljene su dve hipoteze na osnovu pet relevantnih istraživačkih pitanja na koja je data verbalna interpretacija, kao i dodatnih dokaza. Studija preporučuje stvaranje delotvornih mehanizama sprečavanja prevare kako bi se promovisalo stabilno tržišno okruženje, zasnovano na poverenju $i$ orijentisano na rezultate, dok država sa svoje strane mora da pokaže volju da zastupa strategiju za borbu protiv prevara koja je osmišljena i napravljena kako bi podržala operativnu efikasnost osiguravajućih društava i efikasnu isporuku usluga korisnicima osiguranja. Ovaj istraživački rad doprinosi postojećem znanju u tome što pomaže da se ukaže regulatornim telima na potrebu da se kontinuirano angažuju akademici, stručnjaci u oblasti osiguranja, IT stručnjaci i druge zainteresovane strane u osmišljavanju $i$ izgradi održivije strategije za borbu protiv prevara koja bi poboljšala penetraciju i gustinu osiguranja.

Ključne reči: upravljanje zajtevima za naknadu stete, prevara, osiguranje imovine, troškovi potraživanja, otkrivanje i prevencija prevare 